\title{
Densmore et al.
}

\section{${ }^{10}$ Be Analysis}

Samples of channel sediment were collected from the most recently active (generally ephemeral) channel bed, avoiding bars and areas with obvious lateral sediment input from the banks, and were taken 10-50 m upstream from the active trace of the range-bounding fault. In all cases, the channel bed sediment was dominated by medium to coarse sand. Samples were sieved in the field to grain sizes of $0.25-1.18 \mathrm{~mm}$, and were wet-sieved before analysis to $0.25-0.5$ or $0.25-1.0 \mathrm{~mm}$ (Table 1 ). The $0.25-0.5 \mathrm{~mm}$ size fraction was used for the Wassuk Range samples, while the $0.25-1 \mathrm{~mm}$ fraction was used for the Sweetwater samples because of generally finer grain sizes and smaller overall sample volumes. After sieving of the samples, conventional magnetic separation techniques were applied to the $0.25-0.5 \mathrm{~mm}$ or the $0.25-1 \mathrm{~mm}$ size fractions to enrich quartz. Magnetic separation was followed by etching in hot $\mathrm{HCl}$ and in mixtures of weak $\mathrm{HF}$ and $\mathrm{HNO}$ to obtain pure quartz (Kohl \& Nishiizumi, 1992). After dissolution of the quartz, Be was separated by ion exchange chromatography using standard procedures (Ivy-Ochs, 1996; von Blanckenburg et al., 1996), precipitated as $\mathrm{Be}(\mathrm{OH})_{2}$ and transformed to $\mathrm{BeO}$ at $1000^{\circ} \mathrm{C}$. The ${ }^{10} \mathrm{Be} /{ }^{9} \mathrm{Be}$ ratios were measured at the ETH Zürich Tandem accelerator mass spectrometry (AMS) facility (Synal et al., 1997) using ETH AMS standard S555 $\left({ }^{10} \mathrm{Be} /{ }^{9} \mathrm{Be}=95.5 \times 10^{-12}\right.$ nominal $)$ with a ${ }^{10} \mathrm{Be}$ half-life of 1.51 Ma.

Catchment-averaged erosion rates were calculated from blank-corrected ${ }^{10} \mathrm{Be}$ concentrations using CosmoCalc version 0.50 for Macintosh (Vermeesch, 2007). Topographic shielding was calculated with the relaxed algorithm of Codilean (2006) on a 10 m digital topographic model. In CosmoCalc the scaling algorithm of Dunai (2000) was used to calculate the production rate scaling factors for ${ }^{10} \mathrm{Be}$ at catchment mean elevations. The total ${ }^{10} \mathrm{Be}$ production rate used is 5.12 atoms per gram quartz per year. Muon production of ${ }^{10}$ Be was modelled with the algorithm of Schaller et al. (2002) 
which includes production rates of Heisinger et al. (2002). For all other parameters we used the default values of CosmoCalc. Details of sample locations, elevations, grain size fractions, and scaling factors are given in Table DR1. Note that our uncertainties are due to internal sources only and do not include uncertainty in the production rate of ${ }^{10} \mathrm{Be}$. We do this because we are concerned with relative, along-strike variations between different catchments, and a different production rate applied globally to our data will not affect the along-strike pattern. Table DR1 contains all information required to recalculate the denudation rates using any desired production rate.

\section{Long-term Denudation Rates}

To determine long-term denudation rates in the Wassuk fault footwall, we used apatite (U-Th)/He (AHe) samples taken from Mesozoic granitic rocks at the mountain front but at different alongstrike positions, as described by Krugh (2008). Sample collection, processing, and analysis procedures are given in Krugh (2008). Because we wish to determine the rate of exhumation that has resulted directly from slip on the Wassuk fault, we selected only those samples that (1) were collected within $50 \mathrm{~km}$ of the southern Wassuk fault tip, and (2) show evidence of rapid cooling through the AHe partial retention zone (PRZ) since the onset of rapid fault slip at $~ 4$ Ma (Stockli et al., 2002). Determination of rapid cooling was made on the basis of forward temperature-time modelling of apatite fission-track samples taken at the same locations (e.g., Ketcham, 2005), and on agreement between model results and independent AHe cooling ages, as described in Krugh (2008). Sample locations and corrected cooling ages are given in Table DR2. Note that the two oldest AHe ages used in this modelling (sample W01, 5.6 \pm 0.3 and 5.8 $\pm 0.2 \mathrm{Ma}$ ) come from near the southern tip of the Wassuk fault, consistent with later onset of rock uplift and cooling as the fault propagated southwards at 1-2 Ma (Krugh, 2008).

To convert sample cooling ages to denudation rates, we used the numerical program AGE2EDOT (Brandon et al., 1998; Ehlers et al., 2005). This program determines the erosion rate required to 
yield the observed sample cooling age, assuming steady cooling and a simple one-dimensional heat conduction model. Model parameter values (Table DR3) were chosen based on (1) observed high radiogenic heat production rates in the nearby Sierra Nevada Batholith in eastern California (Brady et al., 2006), which is similar in age and composition to the granitic rocks in the Wassuk footwall (John, 1983), and (2) the observed near-surface Pliocene-Recent geothermal gradient of $32 \pm 8^{\circ} \mathrm{C}$ $\mathrm{km}^{-1}$ in the Wassuk region (Stockli et al., 2002). The resulting one-dimensional solution is consistent with a surface heat flow in the absence of erosion of $\sim 100 \mathrm{~mW} \mathrm{~m}^{-2}$, comparable to published values of 75-120 mW m ${ }^{-2}$ in the nearby Mono Basin, Yerington, and Aurora regions (e.g., Sass et al., 2005). Model denudation rates are reported in Table DR2 with $2 \sigma$ uncertainties.

\section{References}

Brady, R.J., Ducea, M.N., Kidder, S.B., and Saleeby, J.B., 2006, The distribution of radiogenic heat production as a function of depth in the Sierra Nevada Batholith, California: Lithos, v. 86, p. 229-244.

Brandon, M.T., Roden-Tice, M.K., and Garver, J.I., 1998, Late Cenozoic exhumation of the Cascadia accretionary wedge in the Olympic Mountains, northwest Washington State: Geological Society of America Bulletin, v. 110, p. 985-1009.

Codilean, A.T., 2006, Calculation of the cosmogenic nuclide production topographic shielding scaling factor for large areas using DEMs: Earth Surface Processes and Landforms, v. 31, p. 785-794.

Dunai, T.J., 2000, Scaling factors for production rates of in situ produced cosmogenic nuclides: a critical reevaluation: Earth and Planetary Science Letters, v. 176, p. 157-169.

Ehlers, T.A., Chaudhri, T., Kumar, S., Fuller, C.W., Willett, S.D., Ketcham, R.A., Brandon, M.T., Belton, D.X., Kohn, B.P., Gleadow, A.J.W., Dunai, T.J., and Fu, F.Q., 2005, Computational tools for low-temperature thermochronometer interpretation: Reviews in Mineralogy and Geochemistry, v. 58, p. 589-622. 
Heisinger, B., Lal, D., Jull, A.J.T., Kubik, P., Ivy-Ochs, S., Neumaier, S., Knie, K., Lazarev, V., and Nolte, E., 2002, Production of selected cosmogenic radionuclides by muons: 1 . Fast muons: Earth and Planetary Science Letters, v. 200, p. 345-355.

Ivy-Ochs, S., 1996, The dating of rock surfaces using in situ produced ${ }^{10} \mathrm{Be},{ }^{26} \mathrm{Al}$, and ${ }^{36} \mathrm{Cl}$, with examples from Antartica and the Swiss Alps: PhD dissertation, ETH Zürich, Zürich, Switzerland, $196 \mathrm{pp}$.

John, D.A., 1983, Map showing distribution, ages, and petrographic characteristics of Mesozoic plutonic rocks in the Walker Lake 1 degree by 2 degree quadrangle, California and Nevada: U.S. Geological Survey Miscellaneous Field Investigations Map MF-1382-B.

Ketcham, R.A., 2005, Forward and inverse modelling of low-temperature thermochronometry data: Reviews in Mineralogy and Geochemistry, v. 58, p. 275-314.

Kohl, C.P., and Nishiizumi, K., 1992, Chemical isolation of quartz for measurement of in-situproduced cosmogenic nuclides: Geochimica et Cosmochimica Acta, v. 56, p. 3583-3587. Krugh, W.K., 2008, Low-temperature thermochronologic constraints on fault array evolution and patterns of range-scale denudation: PhD dissertation, ETH Zürich, Zürich, Switzerland, 94 pp.

Sass, J.H., Priest, S.S., Lachenbruch, A.H., Galanis Jr, S.P., Moses Jr, T.H., Kennelly Jr, J.P., Munroe, R.J., Smith, E.P., Grubb, F.V., Husk Jr, R.H., and Mase, C.W., 2005, Summary of supporting data for USGS regional heat-flow studies of the Great Basin, 1970-1990: U.S. Geological Survey Open-File Report 2005-1207.

Schaller, M., von Blanckenburg, F., Veldkamp, A., Tebbens, L.A., Hovius, N., and Kubik, P.W., 2002, A 30000 yr record of erosion rates from cosmogenic ${ }^{10} \mathrm{Be}$ in Middle European river terraces: Earth and Planetary Science Letters, v. 204, p. 307-320.

Stockli, D.F., Surpless, B.E., and Dumitru, T.A., 2002, Thermochronological constraints on the timing and magnitude of Miocene and Pliocene extension in the central Wassuk Range, western Nevada: Tectonics, v. 21, doi:10.1029/2001TC001295.

Synal, H.A., Bonani, G., Doebeli, M., Ender, R.M., Gartenmann, P., Kubik, P.W., Schnabel, C., and 
Suter, M., 1997, Status report of the PSI/ETH AMS facility: Nuclear Instrumentation and Methods in Physics Research, Section B, v. 123, p 62-68.

Vermeesch, P., 2007, CosmoCalc: An Excel add-in for cosmogenic nuclide calculations:

Geochemistry, Geophysics, Geosystems, v. 8, Q08003, doi:10.1029/2006GC001530.

von Blanckenburg, F., Belshaw, N.S., and O’Nions, R.K., 1996, Separation of ${ }^{9}$ Be and cosmogenic

${ }^{10}$ Be from environmental materials and SIMS isotope dilution analysis: Chemical Geology, v. 129, p. 93-99. 
TABLE DR1. SAMPLE DESCRIPTION, SCALING FACTORS, ${ }^{10}$ BE CONCENTRATIONS, AND DENUDATION RATES

\begin{tabular}{|c|c|c|c|c|c|c|c|c|c|}
\hline Sample & $\begin{array}{l}\text { Sample location } \\
\text { (longitude/latitude) }\end{array}$ & $\begin{array}{c}\text { Sample } \\
\text { elevation } \\
\text { (m) }\end{array}$ & $\begin{array}{l}\text { Grain size } \\
\text { used (mm) }\end{array}$ & $\begin{array}{l}\text { Mean catch- } \\
\text { ment eleva- } \\
\text { tion (m) }\end{array}$ & $\begin{array}{l}\text { Scaling } \\
\text { factor for } \\
{ }^{10} \mathrm{Be}^{\star}\end{array}$ & $\begin{array}{l}\text { Topo. shielding } \\
\text { factor }^{\dagger}\end{array}$ & $\begin{array}{c}{ }^{{ }^{10} \mathrm{Be} \text { concen- }} \\
\text { tration }^{\S} \\
\left(10^{4} \mathrm{at} / \mathrm{g}\right)\end{array}$ & $\begin{array}{l}\text { Denudation } \\
\text { rate } \\
(\mathrm{mm} / \mathrm{ka})^{\#}\end{array}$ & $\begin{array}{c}\text { Denudatior } \\
\text { timescale } \\
(\mathrm{ka})^{* *}\end{array}$ \\
\hline \multicolumn{10}{|c|}{ Sweetwater Range } \\
\hline 04A1 & $118.3402 \mathrm{~W} / 45.0717 \mathrm{~N}$ & 2303 & bedrock & - & 6.226 & 1.000 & $148.7 \pm 8.1$ & $13.42 \pm 0.76$ & 45 \\
\hline 04A4 & $118.3634 \mathrm{~W} / 45.0866 \mathrm{~N}$ & 2128 & $0.25-1.0$ & 2253 & 6.000 & 0.999 & $73.3 \pm 3.4$ & $26.8 \pm 1.3$ & 22 \\
\hline 04A5 & $118.3592 \mathrm{~W} / 45.0792 \mathrm{~N}$ & 2265 & $0.25-1.0$ & 2295 & 6.190 & 1.000 & $140.0 \pm 8.1$ & $14.20 \pm 0.85$ & 42 \\
\hline $04 A 6$ & $118.3465 \mathrm{~W} / 45.0750 \mathrm{~N}$ & 2328 & bedrock & - & 6.343 & 1.000 & $157.4 \pm 7.8$ & $12.89 \pm 0.66$ & 47 \\
\hline 04A10 & $118.4056 \mathrm{~W} / 45.1083 \mathrm{~N}$ & 2134 & $0.25-1.0$ & 2391 & 6.649 & 0.999 & $78.2 \pm 3.8$ & $27.7 \pm 1.4$ & 22 \\
\hline 04A11 & $118.3836 \mathrm{~W} / 45.0929 \mathrm{~N}$ & 2160 & $0.25-1.0$ & 2319 & 6.303 & 0.999 & $59.5 \pm 3.4$ & $34.8 \pm 2.0$ & 17 \\
\hline 04A12 & $118.3034 \mathrm{~W} / 45.0562 \mathrm{~N}$ & 2096 & $0.25-0.5$ & 2180 & 5.678 & 0.998 & $185.1 \pm 6.5$ & $9.73 \pm 0.36$ & 62 \\
\hline 04A13 & $118.2906 \mathrm{~W} / 45.0512 \mathrm{~N}$ & 2032 & $0.25-1.0$ & 2165 & 5.614 & 0.999 & $62.3 \pm 4.9$ & $29.6 \pm 2.4$ & 20 \\
\hline
\end{tabular}




\section{Wassuk Range}

\begin{tabular}{|c|c|c|c|c|c|c|c|c|c|c|}
\hline 05WS1 & $112.5860 \mathrm{~W} / 38.3763 \mathrm{~N}$ & 1850 & $0.25-0.5$ & 2166 & 4.789 & 0.992 & $6.67 \pm 0.99$ & 242 & \pm 36 & 2.5 \\
\hline 05WS2 & $112.7681 \mathrm{~W} / 38.6617 \mathrm{~N}$ & 1288 & $0.25-0.5$ & 1635 & 3.245 & 0.949 & $7.96 \pm 0.61$ & 137 & \pm 11 & 4.4 \\
\hline 05WS3 & $112.7222 \mathrm{~W} / 38.5833 \mathrm{~N}$ & 1447 & $0.25-0.5$ & 2030 & 4.362 & 0.962 & $20.1 \pm 1.7$ & 71.1 & \pm 6.0 & 8.4 \\
\hline 05WS4 & $112.5993 \mathrm{~W} / 38.3441 \mathrm{~N}$ & 1940 & $0.25-0.5$ & 2299 & 5.268 & 0.992 & $4.7 \pm 1.2$ & 377 & \pm 94 & 1.6 \\
\hline 05WS5 & $112.6523 \mathrm{~W} / 38.2251 \mathrm{~N}$ & 2141 & $0.25-0.5$ & 2509 & 6.093 & 0.993 & $23.4 \pm 1.1$ & 86.1 & \pm 4.2 & 7.0 \\
\hline 05WS6 & $112.5894 \mathrm{~W} / 38.3566 \mathrm{~N}$ & 1945 & $0.25-0.5$ & 2245 & 5.069 & 0.990 & $2.72 \pm 0.44$ & 630 & \pm 100 & 1.0 \\
\hline 05WS7 & $112.7026 \mathrm{~W} / 38.5145 \mathrm{~N}$ & 1724 & $0.25-0.5$ & 2149 & 4.751 & 0.986 & $16.4 \pm 2.0$ & 97 & \pm 12 & 6.2 \\
\hline 05WS8 & $112.6916 \mathrm{~W} / 38.5134 \mathrm{~N}$ & 1664 & $0.25-0.5$ & 1837 & 3.768 & 0.990 & $3.00 \pm 0.66$ & 434 & \pm 95 & 1.4 \\
\hline 05WS9 & $112.6386 \mathrm{~W} / 38.3888 \mathrm{~N}$ & 2079 & $0.25-0.5$ & 2512 & 6.139 & 0.993 & $15.5 \pm 2.8$ & 131 & \pm 24 & 4.6 \\
\hline 05WS11 & $112.6000 \mathrm{~W} / 38.4015 \mathrm{~N}$ & 1794 & $0.25-0.5$ & 2287 & 5.232 & 0.992 & $7.51 \pm 0.51$ & 233 & \pm 16 & 2.6 \\
\hline 05WS12 & $112.6201 \mathrm{~W} / 38.4211 \mathrm{~N}$ & 1800 & $0.25-0.5$ & 2068 & 4.463 & 0.991 & $9.48 \pm 0.51$ & 159.4 & \pm 8.6 & 3.8 \\
\hline $05 \mathrm{WS} 13$ & $112.6493 \mathrm{~W} / 38.3331 \mathrm{~N}$ & 2128 & $0.25-0.5$ & 2519 & 6.158 & 0.996 & $34.8 \pm 4.1$ & 58.4 & \pm 7.0 & 10.3 \\
\hline 05WS14 & $112.6264 \mathrm{~W} / 38.3246 \mathrm{~N}$ & 1995 & $0.25-0.5$ & 2486 & 6.015 & 0.996 & $5.90 \pm 0.95$ & 340 & \pm 55 & 1.8 \\
\hline 05WS15 & $112.6126 \mathrm{~W} / 38.3198 \mathrm{~N}$ & 1904 & $0.25-0.5$ & 2454 & 5.879 & 0.996 & $7.7 \pm 1.0$ & 256 & \pm 34 & 2.3 \\
\hline
\end{tabular}

* Scaling factors were calculated using CosmoCalc (Vermeesch, 2007). See text for details.

${ }^{\dagger}$ Topographic shielding was derived from a $10 \mathrm{~m}$ digital elevation model by applying the relaxed version of the shielding algorithm of Codilean (2006).

${ }^{\S}$ Blank-corrected ${ }^{10}$ Be concentrations. Errors are $1 \sigma$. 
${ }^{\#}$ Denudation rates were calculated with a sea level high-latitude ${ }^{10}$ Be production rate of 5.12 at/g/a with CosmoCalc (Vermeesch, 2007$)$. Errors on the denudation rates $(1 \sigma)$ do not include uncertainty in the production rate, which are $\sim 10 \%$. See text for further details.

${ }^{* *}$ Denudation time scale is calculated as the time required to remove $60 \mathrm{~cm}$ of bedrock at the calculated denudation rate. 
TABLE DR2. AHE SAMPLE LOCATIONS, AGES, AND MODEL EROSION RATES

\begin{tabular}{|c|c|c|c|c|}
\hline$\overline{\text { Sample ID }}$ & $\begin{array}{l}\text { Sample location } \\
\text { (easting/northing) }\end{array}$ & $\begin{array}{c}\text { Sample elevation } \\
\text { (m) }\end{array}$ & $\begin{array}{c}\text { Corrected AHe age } \\
\text { (Ma) }\end{array}$ & $\begin{array}{c}\text { Model } \\
\text { denudation rate } \\
\left(\mathrm{mm} \mathrm{kyr}{ }^{-1}\right)\end{array}$ \\
\hline W01a & $355319 / 4235385$ & 2150 & $5.6 \pm 0.3$ & $0.30 \pm 0.01$ \\
\hline W01b & & & $5.8 \pm 0.2$ & $0.30 \pm 0.01$ \\
\hline w04a & $360924 / 4247842$ & 1888 & $2.3 \pm 0.4$ & $0.76 \pm 0.10$ \\
\hline W04b & & & $2.6 \pm 0.5$ & $0.67+0.12 /-0.09$ \\
\hline W04c & & & $3.5 \pm 0.6$ & $0.50+0.10 /-0.07$ \\
\hline W06a & $353680 / 4260695$ & 1593 & $1.1 \pm 0.1$ & $1.5 \pm 0.1$ \\
\hline W06b & & & $3.2 \pm 0.4$ & $0.55+0.07 /-0.06$ \\
\hline
\end{tabular}

\section{TABLE DR3. PARAMETER VALUES FOR AGE2EDOT MODELLING}

\begin{tabular}{lc}
\hline \hline Layer thickness & $30 \mathrm{~km}^{-1}$ \\
Thermal conductivity & $3.3 \mathrm{~W} \mathrm{~m}^{-1} \mathrm{~K}^{-1}$ \\
Surface temperature & $10^{\circ} \mathrm{C}$ \\
Internal heat production rate & $3 \mu \mathrm{W} \mathrm{m}$ \\
Near-surface geothermal gradient ${ }^{\dagger}$ & $32^{\circ} \mathrm{C} \mathrm{km}^{-1}$ \\
Heat capacity & $1000 \mathrm{~J} \mathrm{~kg}^{-1} \mathrm{~K}^{-1}$ \\
& \\
\hline & \\
Typical value for upper 20-30 km of neighboring Sierra Nevada Batholith in eastern California (Brady \\
et al., 2006). \\
${ }^{\dagger}$ Pliocene-Recent geothermal gradient in Wassuk fault footwall from Stockli et al. (2002).
\end{tabular}




\section{Figure Captions}

Figure DR1. Footwall relief and fault rock uplift profiles. A, Footwall relief (grey line) and rock uplift relative to hangingwall basin (dashed line) as functions of distance from northern Sweetwater fault tip. Relief is the difference between minimum and maximum elevations of footwall catchments (grey in A) projected onto a fault-parallel profile (Densmore et al., 2004). Rock uplift profile is constrained by (1) offset of $215 \pm 10 \mathrm{~m}$ at $\mathrm{x}=17 \mathrm{~km}$ from the northern fault tip, and (2) throw of 250-550 m at the strike center. B, Footwall relief (grey line) and rock uplift relative to hangingwall basin (dashed line) as functions of distance from southern Wassuk fault tip. Relief is calculated as in Fig. 1. Rock uplift profile is constrained by estimate of 3.7-4.5 $\mathrm{km}$ at $\mathrm{x}=21 \mathrm{~km}$ from the southern fault tip.

Figure DR2. A, denudation rates as a function of catchment area for the Sweetwater footwall. $\mathrm{B}$, denudation rates as a function of catchment area for the Wassuk footwall. C, denudation rates as a function of total catchment relief for the Sweetwater (white circles) and Wassuk (grey circles) footwalls. Inset shows data from the Sweetwater footwall only. D, denudation rates as a function of mean catchment slope for the Sweetwater (white circles) and Wassuk (grey circles) footwalls. Inset shows data from the Sweetwater footwall only. Note weak correlation, even at mean slopes of $<30^{\circ}$. 

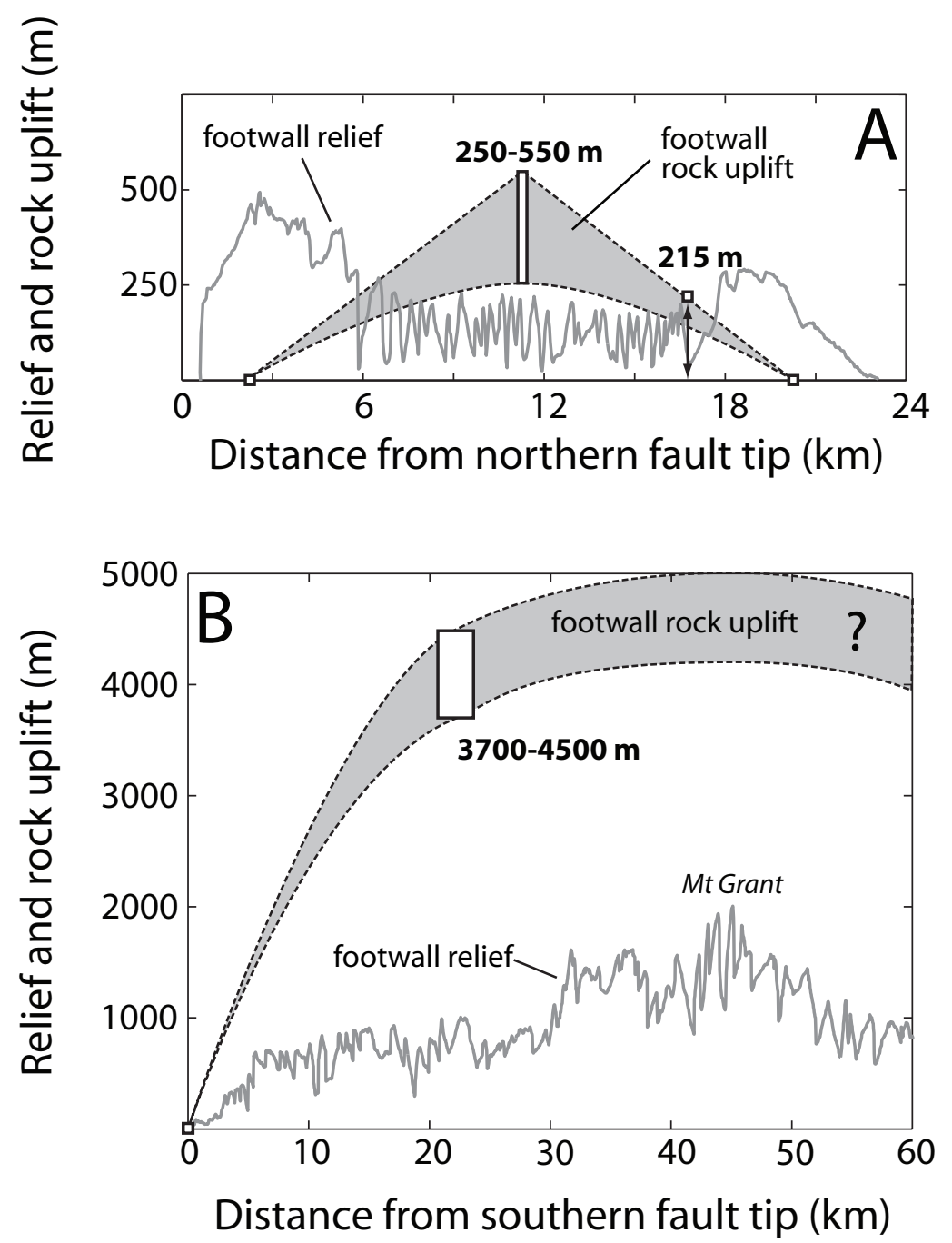

Densmore et al. Figure DR1 

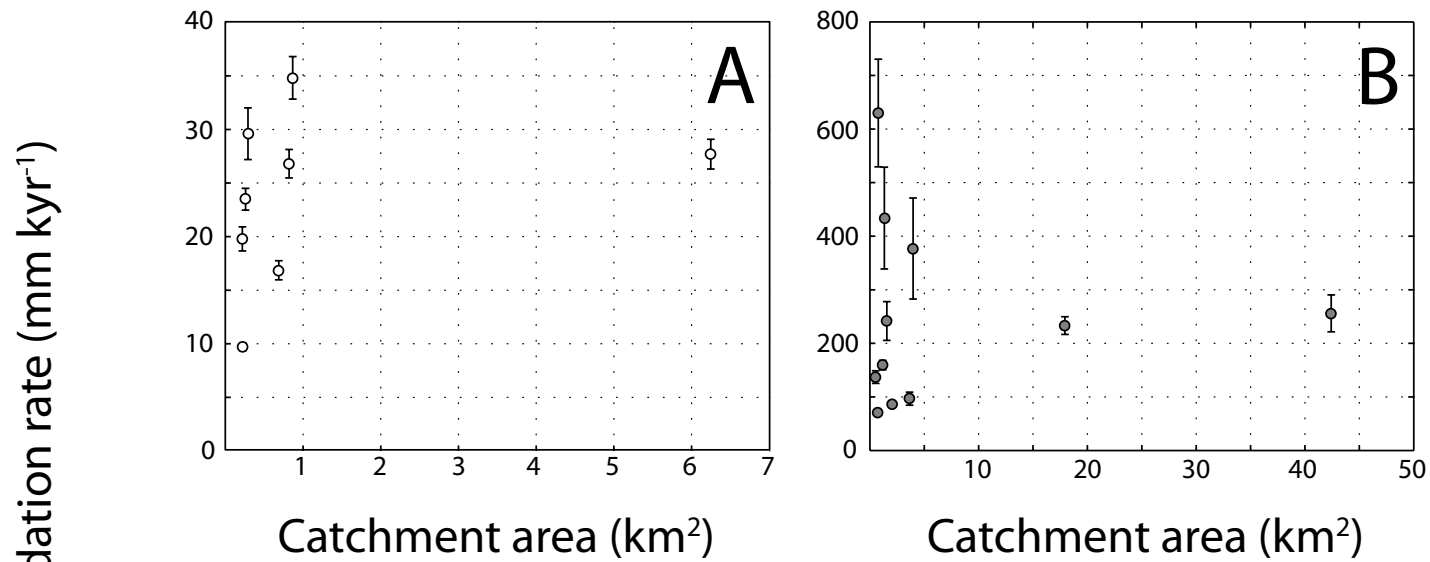

Catchment area $\left(\mathrm{km}^{2}\right)$

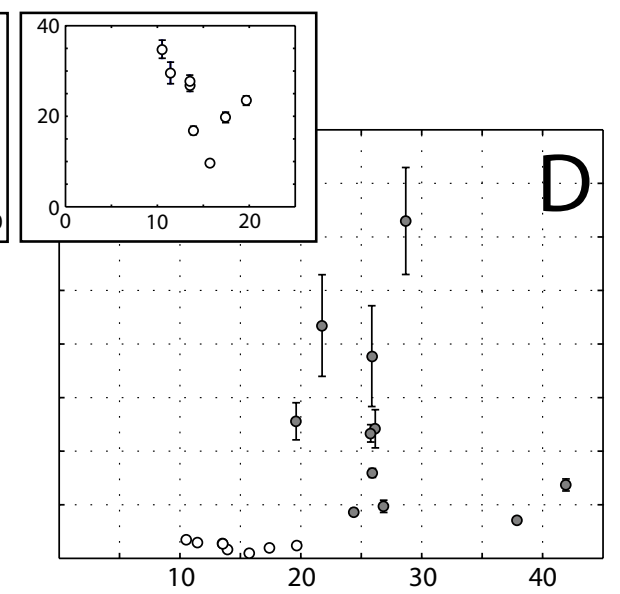

Catchment relief $(\mathrm{m})$

Mean catchment slope (deg) 